\title{
PENERAPAN UNSUR-UNSUR NIRMANA DWIMATRA DALAM TOOLBOX PERANGKAT LUNAK DESAIN CORELDRAW
}

\author{
Edi Jatmiko, Krisna Tanaya Joestiono \\ Program Studi Desain Komunikasi Visual \\ Fakultas Seni Rupa Institut Seni Indonesia Yogyakarta \\ rubahsiang@gmail.com
}

\begin{abstract}
The importance of mastering nirmana, both technical workmanship and theoretical understanding is absolutely owned by a senirupawan, especially in the field of design. The theory of nirmana explains the very foundations in a design that accommodates the fundamental needs in designing a work of art and design. Fundamental elements in Nirmana theory such as points, lines, colors, textures and so on are fundamental elements whose existence is absolutely needed in the process of creating a design.

In its development in the early 2000s, both the industrial world and the academic realm had begun to flourish the use of digital techniques as the main tool and a tool to support the creation of design works. With the development of hardware-based information technology on computer devices, led to the development of work production support software, one of which is in the field of design namely design software namely CorelDRAW.

This study tries to identify the application of nirmana theories, namely Nirmana Dwimatra elements found in CorelDRAW design software. The research is strived to find relationships and linkages of the visual elements contained in nirmana which were initially mastered in theory and technical practice manually applied in digital software tools, menus, submenus.
\end{abstract}

Keywords: Basic principals Designs, elements design

Relevance to Visual Communication Design Practice: This research allows to examine the correlation and relation between the application of the basic principles of design in application software design

\section{PENDAHULUAN}

Pentingnya penguasaan nirmana, baik secara teknis pengerjaan dan pemahaman teoritis mutlak dimiliki oleh serorang senirupawan, terutama dibidang desain. Teori nirmana memaparkan landasan-landasan yang sangat mendasar dalam sebuah desain yang mengakomodasi kebutuhan -kebutuhan fundamental dalam merancang sebuah karya seni rupa dan design. Elemen-elemen fundamental dalam teori Nirmana seperti titik, garis, warna, tekstur dan sebagainya adalah elemen mendasar yang keberadaanya mutlak dibutuhkan dalam proses penciptaan sebuah desain. Sebuah karya seni rupa maupun desain yang memiliki kualitas estetis akan memiliki harmonisasi serta keseimbangan antar garis, bidang, warna, dan elemen lain dalam komposisi bidang dan layout didalamnya.

Semua karya seni rupa dan desain akan selalu diawali dengan titik yang ditarik dengan pola tertentu dan akhirnya menjadi sebuah garis, bentuk-bentuk dan ukuran garis yang bertemu dan saling bersinggungan akan menimbulkan bentuk (shape) bidang datar yang terkadang bisa diidentifikasi sebagai bentuk 
tertentu maupun bentuk abstract. Sebuah bidang datar yang berupa outline akan membutuhkan teknik nirmana yakni bidang gempal, teknik gempal digunakan untuk menciptakan volume atau dimensi seolah memiliki kesan tiga dimensi. Dari bentuk dimensional kemudian digoreskan warna untuk menambah pencapaian estetis tertentu sesuai yang dinginkan seorang desainer.

Pada prinsipnya baik desainer yang berlatar belakang akademis maupun desainer yang mempelajari ilmu desain non akademis mutlak membutuhkan penguasaan teori nirmana untuk mampu menciptakan karya yang memiliki kualitas estetis. Sebagai teori yang sangat fundamental, nirmana merupakan induk dari pengembangan teknik-teknik visual dengan berbagai metode/cara penciptaan maupun format media. Sebagai sebuah teori yang dibakukan secara akademis, maka Nirmana merupakan salah satu mata kuliah dasar yang wajib diselenggarakan oleh lembaga perguruan tinggi dibidang seni rupa dan desain. Selain perguruan tinggi, teori nirmana juga diajarkan disekolah menengah berbasis kejuruan terutama jurusan senirupa dan desain.

Pada awal kegiatan produksi karya desain, terutama desain komunikasi visual, penerapan nirmana pada karya desain menggunakan alat-alat yang pengoperasiannya menggunakan teknik non-digital, yakni pensil, pensil warna, tinta china, cat poster, kuas/brush, stensil, cap, intaglio, hingga menggunakan teknik semprot kompresor. Sehingga pola penerapan teori nirmana pada karya desain untuk kebutuhan tertentu bisa diaplikasikan dengan peralatan-peralatan yang sama ketika merancang karya nirmana.

Pada perkembangannya awal tahun 2000an, baik dunia industri maupun diranah akademik sudah mulai marak penggunaan teknik digital sebagai alat utama maupun pendukung penciptaan karya desain. Dengan berkembanganya teknologi informasi berbasis hardware pada perangkat komputer, memunculkan pengembangan perangkat lunakperangkat lunak penunjang produksi kerja, salah satunya dalam bidang desain yakni perangkat lunak desain yakni CorelDRAW. Software CorelDRAW adalah sebuah perangkat lunak merupakan pengolah grafis dengan berbasis vektor atau garis, dimana unsur dasar yang mendasarinya adalah garis. Keuntungan dari grafis jenis vektor ini adalah gambar akan mempunyai ukuran kapasitas file yang relatif kecil apabila dibandingkan dengan pengolah grafis berbasis bitmap.

Era tahun awal tahun 2000-an, di Indonesia, terutama dikota-kota besar yang terdapat pusat-pusat pendidikan seperti Jakarta, Bandung, Yogyakarta dan Surabaya mulai marak distribusi perangkat komputer untuk masyarakat umum. Komputer-komputer dipasaran sudah mulai dikembangkan teknologinya namun disaat yang sama mengalami penurunan harga. Dampaknya adalah kepemilikan perangkat komputer mulai menyebar, tidak hanya di gedung-gedung perkantoran saja, namun sudah merambah ke ruang-ruang akademik serta agensi-agensi periklanan. Teknis pengerjaan karya-karya desain secara masif mulai tergantikan dengan perangkat perangkat lunak CorelDRAW. Hingga saat ini manakala sudah ada kompetitor dari perusahaan perangkat lunak Adobe yakni Adobe Illustrator, namun penggunaan CorelDRAW masih lazim digunakan.

Dengan hadirnya perangkat lunak desain yang mendukung produksi karya desain, memberikan semacam "jalan pintas" pada penguasaan skill kompetensi seorang desainer. Ketika kemampuan menggaris, memberikan bentuk dan bidang, memberikan volume, warna dan tekstur serta kemampuan mengolah 
komposisi pada bidang atau media gambar dalam teori nirmana tergantikan oleh tools perangkat lunak CorelDRAW muncul anggapan teori nirmana sudah tidak diperlukan lagi. Bagaimanapun juga secara akademis dengan sudut pandang ilmiah, penguasaan nirmana baik secara teori maupun teknis adalah kompetensi fundamental yang wajib dimiliki seorang desainer profesional. Meskipun ada anggapan penguasaan skill nirmana sudah tergantikan dengan tools perangkat lunak, namun jika kita teliti lebih mendalam, maka sebenarnya perangkat lunak CorelDRAW tidak lepas dari unsur-unsur teori nirmana. Berdasarkan permasalahan diatas, maka penelitian ini mencoba mengidentifikasi penerapan teori-teori nirmana yakni unsurunsur Nirmana Dwimatra yang terdapat pada perangkat lunak desain CorelDRAW. Penelitian diupayakan untuk mencari hubungan dan kaitan unsur-unsur rupa yang terdapat dalam nirmana yang awalnya dipenguasaan teori maupun teknis praktiknya secara manual yang diterapkan dalam tools, menu, submenu secara perangkat lunak digital. Nirmana; Dasar Dasar Tata Rupa dan Desain, yang dituis oleh Drs. Sadjiman Ebdi Sanyoto, karena buku ini secara akademis paling banyak digunakan untuk pegangan dan acuan materi mata kuliah nirmana baik untuk perguruan tinggi maupun sekolah menengah kejuruan seni rupa, dan software CorelDRAW merupakan software desain berbasis editor grafik vector yang paling pemula sebelum ada softwareserupa di era-era setelahnya.

\section{NIRMANA}

Berumber dari buku Nirmana; DasarDasar Tata Rupa dan Desain, yang dituis oleh Drs. Sadjiman Ebdi Sanyoto, menyebutkan bahwa Nirmana adalah pengorganisasian atau penyusunan elemen-elemen visual seperti titik, garis, ruang, warna dan tekstur menjadi satu kesatuan yang harmonis. Nirmana dapat juga diartikan sebagai hasil angan-angan dalam bentuk dwimatra, trimatra yang harus mempunyai nilai keindahan. Nirmana disebut juga ilmu tatarupa.

Nirmana merupakan salah satu teori fundamental dalam bidang keilmuan seni rupa. Teori nirmana memparkan landasan-landasan yang sangat mendasar dalam sebuah desain yang mengakomodasi kebutuhan-kebutuhan fundamental dalam merancang sebuah karya seni rupa dan design. Elemen-elemen fundamental dalam teori Nirmana seperti titik, garis, warna, tekstur dan sebagainya adalah elemen mendasar yang keberadaanya mutlak dibutuhkan dalam proses penciptaan sebuah desain. Sebuah karya seni rupa maupun desain yang memiliki kualitas estetis akan memiliki harmonisasi serta keseimbangan antar garis, bidang, warna, dan elemen lain dalam komposisi bidang dan layout didalamnya.

Kata "nirmana", jika dicari dalam kamus bahasa Kawi (Jawa Kuno), Nir artinya "tidak ada atau tanpa", Mana artinya "angan-angan", sehingga Nirmana artinya "tidak ada atau tanpa angan-angan". Jika itu yang dimaksud, barangkali ada benarnya, karena dalam praktek berkarya nirmana, senyatanya tanpa mengangan-angankan sesuatu bentuk (ujud/rupa), tetapi hanya menyusun unsurunsur (elemen) senirupa dan desain, untuk memperoleh keindahan. Ada yang mengartikan Nirmana adalah "tidak ada ujud". Inipun juga ada benarnya karena dalam berkarya nirmana tidak akan mewujudkan sesuatu bentuk (ujud/ rupa).

\section{Unsur-unsur nirmana}

1) Titik 
Prisip dasar desain elementer (nirmana) adalah: Pengorganisasian unsur-unsur/ elemen seni dan desain menjadi karya seni dan atau desain yang artistik (memiliki nilai keindahan) dalam bentuk dua dimensi (2D/ Dwimatra) atau tiga dimensi (3D/Trimatra). Analisis Unsur-unsur/Elemen Seni dan Desain: Bentuk, Raut, Ukuran, Arah, Warna, Value, Tekstur, dan Ruang, sebagai bahan me"rupa".

a) Sentuhan suatu alat, tetesan, percikan, semprotan cairan (pewarna), noda, atau bintik, pada suatu permukaan/tafril akan menghasilkan bekas. Bekas tersebut disebut titik atau spot. Definisi titik adalah suatu bentuk kecil tanpa dimensi. Pasir, kerikil, batu, kelereng, biji-bijian, dan semacamnya yang tanpa dimensi dapat dibayangkan sebagai titik. Begitu juga bentuk rumah, mobil, pohon, bahkan bintang dilangit dapat dibayangkan sebagai titik, karena kecil itu nisbi.

b) Gambar dengan sentuhan titik-menitik, dengan cipratan-cipratan (noda), atau dengan semprotan (bintik-bintik), disebut susunan titik nyata.

c) Tatanan batu, kerikil, pasir, kelereng, pecahan-pecahan keramik, bisa disebut susunan titik semu.

2) Garis

Definisi garis adalah suatu hasil goresan, disebut garis nyata atau kaligrafi, batas limit benda, batas sudut ruang, batas warna, bentuk massa, rangkaian massa, dll. disebut garis semu/ maya/ imajiner. Adapun jenis garis dikategorikan kedalam dua jenis yakni:

a) Garis nyata (kaligrafi)

Sentuhan alat pada permukaan akan menghasilkan titik. Jika titik tersebut digerakkan/digeserkan akan meninggalkan bekas disebut garis.
Disebut garis karena bentuknya kecil hanya berdimensi memanjang. Kecil dan memanjang sifatnya nisbi. Garis hasil goresan ini disebut garis nyata atau garis kaligrafi. Setiap menggambar, menulis, atau mewujudkan suatu bentuk biasanya dilakukan dengan coretancoretan garis, adalah merupakan bentuk garis nyata atau kaligafi. Tulisan tangan (latin, arab, kanji, jawa, dll.) adalah merupakan hasil garis nyata atau kaligrafi. Kaligrafi merupakan hasil goresan langsung yang kadang-kadang kuat, lembut, gemulai, kadang-kadang melesat lancar, dsb. Garis kaligrafi merupakan contoh suatu simbol emosi (seseorang) yang diekspresikan dalam goresan. Garis terdiri dari garis lurus dan garis bengkok/lengkung. Garis lurus adalah positif, tegas, langsung, keras, kuat, tegar, teguh hati, tidak kenal kompromi. Garis lengkung ramping ringan, fleksibel, harmonis, kalem, feminin, tenang, sopan, tetapi cenderung malas, kabur, tidak bertujuan, tidak tegas. Garis nyata hasil gambar atau tulisan dapat memperlihatkan karakter seseorang. Karakter seseorang dapat dilihat melalui coretan gambarnya atau tulisannya. Dengan belajar garis dalam menggambar atau menullis dapat menghaluskan budipekerti seseorang.

b) Garis semu/maya/imajiner

Jika kita menjajarkan titik-titik atau kerikil secara berimpit akan membentuk garis, yang merupakan garis semu/maya/imajiner. Jika kita melihat kawat listrik, seutas tali, senar gitar, atau apa saja yang berdimensi memanjang, dapat dibayangkan sebagai garis. Jika kita melihat sederetan mobil diparkir 
ditepi jalan, gerbong-gerbong kereta api, sederetan gunung-gunung dikejauhan, kita seakan melihat garis. Walupun tugu Monas itu memiliki lebar dan tebal, tetapi karena sifat panjang vertikalnya berlebih maka kita seolah melihat garis vertikal.

3) Bidang.

Bidang adalah suatu bentuk dengan raut pipih/ gepeng datar sejajar tafril memiliki dimensi panjang dan lebar serta menutupi permukaan. Bentuk yang pipih seperti: tripleks, kertas, karton, seng, papan tulis, dsb., sekalipun memiliki tebal tetapi relatif sangat tipis, digolongkan sebagai bidang.

Terdapat 2 pengertian bidang, yaitu:

a) Bidang sebagai bentuk ruang yang disebut ruang dwimatra,

b) Bidang sebagai bentuk raut yang menempati ruang.

Bidang sebagai bentuk ruang disebut ruang dwimatra, yang merupakan bidang datar tempat bentuk-bentuk berada (exist). Ujudnya dapat kertas, tripleks, karton, kanvas, seng, papan tulis, tembok, dll. Bidang sebagai ruang barangkali dapat disebut bidang trimatra karena sesungguhnya memiliki ketebalan walau sangat tipis. Jika disebut ruang dwimatra karena ketebalannya tidak diperhitungkan. Bidang sebagai ruang bisa dibedakan menjadi dua macam, yaitu ruang positif (terisi obyek) dan ruang negatif (ruang yang kosong).

Bidang sebagai bentuk raut yang menempati ruang dapat berujud gambar bidang datar sejajar tafril yang memiliki panjang dan lebar, atau dapat berbentuk maya, yaitu bidang yang seolah-olah melengkung bergelombang, bidang yang seolah-olah membuat sudut-sudut dengan tafril, bidang yang membentuk perspektif, bidang yang muntir, dll., sehingga seolaholah memiliki kedalaman maya. Bidang sebagai bentuk yang menempati ruang juga dapat berujud potongan-potongan lembaran kertas, tripleks, karton, seng, plastik, dsb., yang bisa disusun pada tafril/ ruang datar.

4) Gempal/Volume,

Gempal/volume adalah suatu bentuk yang memiliki tiga dimensi: panjang, lebar, tebal, yang merupakan bentuk wungkul dapat diraba. Hampir semua bentuk di alam ini berujud gempal. Kertas atau seng yang merupakan bidang yang sangat tipis sekalipun juga memiliki ketebalan. Karena bentuk gempal merupakan tiga dimensi penuh yang dapat diraba maka ia menempati ruang tiga dimensi/ruang trimatra/ alam semesta. Bentuk gempal terdiri dari dua macam, yaitu gempal nyata dan gempal semu/maya. Gempal nyata adalah gempal dalam bentuk trimatra (3 dimensi) dapat diraba. Gempal semu/maya adalah bentuk (form) berujud gambar yang dilukis pada tafril/ bidang datar/kertas gambar. Bentuk gempal (volume) dapat berujud padat (berisi) dan kosong (berlubang/ berongga/ bolong). Bentuk gempal dapat digolongkan menjadi dua jenis yaitu jenis gempal (volume) beraturan dan dan jenis gempal (volume) tidak beraturan.

Gempal/volume memiliki: Raut, Ukuran, Arah, Warna, Value, Tekstrur. Gempal (volume) pada dasarnya adalah suatu bentuk ujud yang memiliki ketebalan, baik nyata ataupun maya.

Ciri khas bentuk gempal, meliputi:

a) Gempal kubistis (bersudut-sudut)

b) Gempal silindris (membulat)

c) Gempal gabungan (kubistis dan silindris) 
d) Gempal variasi (berbentuk bebas)

\section{5) Warna}

Warna seperti halnya bunyi merupakan fenomena getaran/gelombang cahaya. Warna merupakan getaran/gelombang yang diterima indera penglihatan, sedangkan bunyi merupakan getaran yang diterima indera pendengaran. Warna warni adalah sama dengan not-not musik atau tangga nada suara. Warna-warna pelangi: ungu/ violet, indigo, biru, hijau, kuning, jingga, merah, merupakan tangga warna, dpt disama kan dengan not musik: do. re. mi. fa. so. la. si. (1.2.3.4.5.6.7) yang merupakan tangga nada musik/ suara.

Warna dapat didefinisikan secara :

a) Objektif/fisik sebagai sifat cahaya yang dipancarkan

b) Subjektif/psikologis sebagai bagian dari pengalaman indera penglihatan.

Secara obyektif/fisik, warna dapat diperikan oleh panjang gelombang. Dilihat dari panjang gelombang, cahaya yang nampak oleh mata merupakan salahsatu bentuk pancaran energi yang merupakan bagian yang sempit dari gelombang elektromagnetik.

\section{PERANGKAT LUNAK DESAIN CORELDRAW}

Pengertian software adalah program komputer yang menjadi jembatan antara pengguna dengan perangkat keras. Ia juga dapat didefinisikan sebagai sebuah aplikasi yang tersusun dari sekumpulan kode-kode bahasa pemrograman disimpan secara digital dan tidak berwujud, namun berada di dalam computer, berisi kumpulan data-data elektronik berupa program atau instruksi yang disimpan dan dikelola oleh komputer. Software dirancang dan dibuat oleh seorang programmer dengan bahasa pemrograman tertentu yang selanjutnya dikompilasi hingga menjadi sebuah kode yang dapat dikenali oleh hardware, selanjutnya dapat dikenali oleh user/manusia yang memakainya. Software dirancang untuk memudahkan aktifitas-aktifitas yang bersifat profit dan non profit untuk menunjang kehidupan manusia, misalnya untuk menghitung, membuat dokumen, mengolah gambar dan lain-lain.

Dalam "A short history of CorelDRAW, Celebrating 20 years of innovation in design" pada laman official websites Corel Corporation, memaparkan bahwa perangkat lunak CorelDRAW awalnya didirikan oleh seorang staf dari Corel Corporation yakni Dr. Michael Cowpland pada tahun 1985. Dr. Michael Cowpland menjual produk Corel kepada Intel Based Desktop Publishing System, yang merupakan sejarah awal dibuatnya CorelDRAW. Kemudian pada tahun 1987, Corel Corporation merekrut Michel Bouillon dan Pat Beirnet sebagai programer. Setelah terjadi kesepakatan antara corel corporation dan Intel Based Dekstop Publishing System, akhirnya CorelDRAW atau tepatnya CorelDRAW 1.0 dirilis pada tahun 1989 bersamaan dengan diluncurkannya Windows 3.1 .

\section{Toolbox CoreIDRAW}

Merujuk pada "A short history of CorelDRAW, Celebrating 20 years of innovation in design" menerangkan bahwa CorelDRAW merupakan salah satu perangkat lunak pionir sebagai penunjang kerja editor grafik dengan jenis format grafik vektor dan grafik raster. Format file utama dari CorelDRAW adalah *.cdr. Perangkat lunak CorelDraw memiliki fasilitas mampu mengedit 
beragam file ekstensi $*$.cdr dengan perangkat lunak lain seperti: Adobe Illustrator, Corel PaintShop Photo Pro, Corel WordPerfect Office, Inkscape, LibreOffice, Macromedia Freehand, Microsoft Visio 2002, sK1, Xara Designer Pro, dan Xara Photo \& Graphic Designer.

Dalam perangkat lunak CorelDraw terdapat 17 toolbox dan 76 sub tools yang digunakan sebagai alat merancang sebuah desain. Toolbox pada CorelDRAW bisa diartikan sebagai kotak perkakas yang berisi tools yang berfungsi untuk membuat, memodifikasi, merubah ukuran, merubah bentuk, mewarnai objek. Beberapa tools secara default terlihat pada Toolbox, secara default terdapat di barisan sebelah kiri tampilan layar, namun tidak semua tools tampil karena ada 76 sub tools. Untuk mengakses sub tools terdapat falyout saat kita klik bagian panah dipojok bawah hingga muncul susunan sub tools yang sesuai klasifikasi tool utama.

\section{HASIL IDENTIFIKASI UNSUR-UNSUR DALAM BUKU "NIRMANA; DASAR- DASAR TATA RUPA DAN DESAIN"}

Unsur-unsur nirmana adalah bagian terkecil dari suatu objek atau komposisi. Unsur tersebut adalah objek untuk menerapkan asas atau prinsip nirmana. Sehingga penting bagi kita untuk mengetahui objek dua dimensi apa saja yang dapat diterapkan asas-asas Nirmana Dwimatra. Adapun Unsur-unsur Nirmana Dwimatra menurut Wucius Wong dalam "Principles of Two-Dimensional Design" terdiri dari (1) Unsur Konseptual yakni: Titik, Garis, Bidang (Plane), Volume (Gempal), (2) Unsur Visual yakni terdiri dari: Bentuk (Shape), Ukuran, Warna, (3) Unsur Relasional yakni terdiri dari: Arah, Posisi, Ruang (Space), Gravitasi, (4) Unsur Praktis yakni terdiri dari:
Representasi (Representation), Makna/Arti (Meaning), Fungsi (Function).

Berdasar buku Nirmana; Dasar-Dasar Tata Rupa dan Desain yang ditulis oleh Drs. Sadjiman Ebdi Sanyoto, Elemen-elemen seni rupa dapat dikelompokan menjadi 4 bagian berdasarkan bentuknya. Pertama adalah titik, titik adalah suatu bentuk kecil yang tidak mempunyai dimensi. Raut titik yang paling umum adalah bundaran sederhana, mampat, tak bersudut dan tanpa arah. Kedua adalah garis, garis adalah suatu hasil goresan nyata dan batas limit suatu benda, ruang, rangkaian masa dan warna. Ketiga adalah bidang, bidang adalah suatu bentuk pipih tanpa ketebalan, mempunyai dimensi pajang, lebar dan luas; mempunyai kedudukan, arah dan dibatasi oleh garis. Keempat adalah Gempal, gempal adalah bentuk bidang yang mempunyai dimensi ketebalan dan kedalaman. Adapun hasil identifikasi unsur niramana tersebut di kelompokkan dalam table berikut:

Tabel 1 Hasil identifikasi unsur-unsur nirmana

\begin{tabular}{|r|l|l|}
\hline No. & $\begin{array}{l}\text { Unsur } \\
\text { nirmana }\end{array}$ & Penjelasan \\
\hline 1. & Titik & $\begin{array}{l}\text { Suatu bentuk kecil yang tidak } \\
\text { mempunyai dimensi. }\end{array}$ \\
\hline 2. & Garis & $\begin{array}{l}\text { garis adalah suatu hasil } \\
\text { goresan nyata dan batas limit } \\
\text { suatu benda, ruang, rangkaian } \\
\text { masa dan warna. }\end{array}$ \\
\hline 3. & Bidang & $\begin{array}{l}\text { Bidang adalah suatu bentuk } \\
\text { pipih tanpa ketebalan, } \\
\text { mempunyai dimensi pajang, } \\
\text { lebar dan luas; mempunyai } \\
\text { kedudukan, arah dan dibatasi } \\
\text { oleh garis. }\end{array}$ \\
\hline 4. & $\begin{array}{l}\text { Gempal/ } \\
\text { volume }\end{array}$ & $\begin{array}{l}\text { Gempal adalah bentuk bidang } \\
\text { yang mempunyai dimensi } \\
\text { ketebalan dan kedalaman. }\end{array}$ \\
\hline 5. & Ruang & $\begin{array}{l}\text { Dalam karya 2 dimensi, ruang } \\
\text { bersifat semu karena hanya } \\
\text { berupa penggambaran saja. } \\
\text { Sementara dalam karya 3 } \\
\text { dimensi, ruang bersifat nyata } \\
\text { dan dapat dirasakan secara } \\
\text { langsung. }\end{array}$ \\
\hline
\end{tabular}




\begin{tabular}{|r|l|l|}
\hline 6. & Warna & $\begin{array}{l}\text { Pigment yang terdapat pada } \\
\text { permukaan bidang pada suatu } \\
\text { karya }\end{array}$ \\
\hline 7. & Tekstur & $\begin{array}{l}\text { sifat dan keadaan permukaan } \\
\text { bidang pada suatu karya. Tiap } \\
\text { benda tentu memiliki tekstur } \\
\text { yang berbeda-beda, meski ada } \\
\text { juga yang hampir sama. } \\
\text { Tekstur terdiri atas dua jenis } \\
\text { yaitu nyata dan semu. }\end{array}$ \\
\hline
\end{tabular}

\section{Tampilan area kerja CoreIDRAW}

Mengenal Area Kerja CorelDRAW terdiri dari : (1.) Title Bar Judul untuk program yang sedang aktif / file yang digunakan CorelDRAW. (2.) Menu Bar Terdiri dari baris perintah menu yang terdiri dari 12 menu, untuk mengoperasikan menumenu tersebut, klik menu yang dituju atau dapat menggunakan tombol shortcut. (3.) Standar Tool Bar Kumpulan tool-tool yang digunakan untuk mempermudah dan mempercepat kerja. (4.) area yang diguanakan sebagai Property Bar.

\section{a. Data Visual tools pada toolbox CorelDRAW}

Dalam perangkat lunak CorelDraw terdapat 15 toolbox dan 73 sub tools yang digunakan sebagai alat merancang sebuah desain. Toolbox pada CorelDRAW bisa diartikan sebagai kotak perkakas yang berisi tools yang berfungsi untuk membuat, memodifikasi, merubah ukuran, merubah bentuk, mewarnai objek. Beberapa tools secara default terlihat pada Toolbox, secara default terdapat di barisan sebelah kiri tampilan layar, namun tidak semua tools tampil karena ada 73 sub tools. Untuk mengakses sub tools terdapat falyout saat kita klik bagian panah dipojok bawah hingga muncul susunan sub tools yang sesuai klasifikasi tool utama. Berikut hasil data visual dari pengamatan dan observasi pada software CorelDRAW, dalam penelitian ini adalah CorelDRAW 2019.

\section{b. Penjelasan fungsi masing tools dalam toolbox CorelDRAW}

Tabel 2 Penjelasan fungsi masing tools dalam toolbox CorelDRAW

\begin{tabular}{|c|c|c|}
\hline No. & \multicolumn{2}{|c|}{ Keterangan dan Fungsi } \\
\hline \multicolumn{3}{|c|}{ Pick tool } \\
\hline & \multicolumn{2}{|c|}{$\begin{array}{l}\text { Mengaktifkan obyek dan untuk melakukan editing } \\
\text { dasar dari obyek misalnya scaling, rotating, } \\
\text { skewing, resizing }\end{array}$} \\
\hline \multicolumn{3}{|c|}{ Shape Tools } \\
\hline 1. & Shape Tool & $\begin{array}{l}\text { Melakukan proses editing } \\
\text { node pada shape (komponen } \\
\text { garis dari obyek). }\end{array}$ \\
\hline 2. & Smudge Tool & $\begin{array}{l}\text { Menggosok obyek sehingga } \\
\text { merubah bentuk obyek yang } \\
\text { digosok tersebut. }\end{array}$ \\
\hline 3. & Roughen Tool & $\begin{array}{l}\text { Memberikan efek distorsi } \\
\text { pada obyek. }\end{array}$ \\
\hline 4. & Transform Tool & $\begin{array}{l}\text { Merotasi, membesarkan, } \\
\text { mengecilkan, } \\
\text { skewing image secara bebas. }\end{array}$ \\
\hline \multicolumn{3}{|c|}{ Crop Tools } \\
\hline 1. & Crop Tool & $\begin{array}{l}\text { Digunakan untuk menghapus } \\
\text { objek diluar seleksi. }\end{array}$ \\
\hline 2. & Knife Tool & $\begin{array}{l}\text { Pisau yang berfungsi untuk } \\
\text { memotong obyek. }\end{array}$ \\
\hline 3. & Eraser Tool & $\begin{array}{l}\text { Menghapus bagian tertentu } \\
\text { dari obyek. }\end{array}$ \\
\hline 4. & $\begin{array}{l}\text { Virtual Segment } \\
\text { delete tool }\end{array}$ & $\begin{array}{l}\text { Menghapus segmen secara } \\
\text { virtual }\end{array}$ \\
\hline \multicolumn{3}{|c|}{ Zoom Tools } \\
\hline 1. & Zoom Tool & $\begin{array}{l}\text { Membesarkan atau } \\
\text { mengecilkan tampilan area } \\
\text { kerja di }\end{array}$ \\
\hline 2. & Hand Tool & $\begin{array}{l}\text { Menggeser area kerja ke } \\
\text { posisi tertentu. }\end{array}$ \\
\hline \multicolumn{3}{|c|}{ Curve Tools } \\
\hline 1. & Freehand Tool & $\begin{array}{l}\text { Membuat obyek berupa garis } \\
\text { bebas. }\end{array}$ \\
\hline 2. & Bezier Tool & $\begin{array}{l}\text { Membuat obyek garis dengan } \\
\text { menentukan banyaknya node. }\end{array}$ \\
\hline 3. & $\begin{array}{l}\text { Artistic Media } \\
\text { Tool }\end{array}$ & $\begin{array}{l}\text { Membuat obyek garis dengan } \\
\text { berbagai bentuk yang artistik }\end{array}$ \\
\hline 4. & Pen Tool & $\begin{array}{l}\text { Membuat obyek kombinasi } \\
\text { antara garis lurus dan garis } \\
\text { lengkung secara langsung. }\end{array}$ \\
\hline 5. & Polyline Tool & $\begin{array}{l}\text { Membuat obyek kombinasi } \\
\text { garis lurus dan freehand } \\
\text { secara langsung. }\end{array}$ \\
\hline
\end{tabular}









\begin{tabular}{r|l|l}
\hline 13 & $\begin{array}{l}\text { Pattern fill } \\
\text { dialog }\end{array}$ & $\begin{array}{l}\text { Memunculkan kotak dialog } \\
\text { pola. }\end{array}$ \\
\hline 14 & $\begin{array}{l}\text { Texture fill } \\
\text { dialog }\end{array}$ & $\begin{array}{l}\text { Memunculkan kotak dialog } \\
\text { tekstur. }\end{array}$ \\
\hline 15 & $\begin{array}{l}\text { Postscript fill } \\
\text { dialog }\end{array}$ & $\begin{array}{l}\text { Memunculkan kotak dialog } \\
\text { postscript. }\end{array}$ \\
\hline 16 & No fill & Menghilangkan warna isi. \\
\hline 17 & $\begin{array}{l}\text { Color docker } \\
\text { dialog }\end{array}$ & $\begin{array}{l}\text { Memunculkan color docker } \\
\text { window untuk warna isi. }\end{array}$ \\
\hline
\end{tabular}

merupakan sebuah rekayasa hasil dari representasi penerapan teori dasar nirmana. Sebagai sebuah alat atau piranti pembuat karya seni rupa dan desain maka secara struktur developing yang dilakukan disusun dari unsur-unsur nirmana. Pada penelitian ini proses terjadinya penerapan unsur-unsur nirmana kedalam software CorelDRAW

\section{Pola relasi unsur-unsur nirmana dengan tools pada toolbox CorelDRAW}

Seperti halnya software design lainnya, CorelDRAW merupakan software yang dibangun sebagai Software Development Life Cycle. Semua atribut dan feature yang ada dalam software design ditujukan untuk mempermudah dalam merancang sebuah karya senirupa secara teknis, serta untuk mempersingkat durasi pengerjaan secara alokasi waktu. Swebok (2004) mendefinsikan bahwa software design adalah semua proses dalam mendefinisikan arsitektur, komponen, interface dan karateristik sebuah sistem dan/atau komponen lainnya serta hasil dari proses tersebut. Pendapat lain mengatakan bahwa software design adalah merupakan rekayasa representasi yang berarti terhadap sesuatu yang hendak dibangun. Hasil rancangan harus dapat ditelusuri hingga ke spesifikasi kebutuhan yang dapat diukur kualitasnya berdasarkan kriteria-kriteria rancangan yang bagus. Perancangan menekankan pada solusi logik mengenai cara sistem memenuhi kebutuhan(Bambang Hariyanto, 2004).

Ketika teori fundamental seni rupa yakni nirmana yang dirumuskan kedalam sebuah buku karya Sadjiman Ebdi Sanyoto dalam bukunya Nirmana; Dasar-Dasar Tata Rupa dan Desain yang diwujudkan kedalam sebuah software desain berbasis digital yakni CorelDRAW, maka software tersebut menggunakan prinsip-prinsip dalam melakukan desain software (Swebok 2004). Adapun proses penerapan teori kedalam sebuah perangkat/piranti software pembuat desain, maka setidaknya terjadi beberapa pola yakni:

\section{a. Abstraction (Proses Abstraksi)}

Abstraksi merupakan salah satu teknik yang paling ampuh untuk menyelesaikan sebuah permasalahan yang kompleks. Abstraksi merupakan kemampuan manusia untuk mengenali keserupaankeserupaan diantara objek-objek, situasisituasi, dan proses-proses di dunia nyata serta keputusan untuk berkonsentrasi pada keserupaan-keserupaan tersebut dan mengabaikan apa yang disebut perbedaan-perbedaan kecil yang ada (Bambang Hariyanto, 2004). Sedangkan pendapat lain mengatakan bahwa abstraksi adalah proses menghilangkan informasi dari sebuah objek dan menjadikan perbedaan-perbedaan kecil sebagai suatu kesamaan untuk maksud tertentu (Swebok, 2004).

Adapun proses abstraksi yang berasal dari teori fundamental seni rupa yakni nirmana yang dirumuskan kedalam sebuah buku karya Sadjiman Ebdi Sanyoto dalam bukunya Nirmana; DasarDasar Tata Rupa dan Desain yang di wujudkan kedalam sebuah software desain berbasis digital yakni adanya 
penyerupaan-penyerupaan alat dan fungsi yang ada dalam kehidupan nyata untuk menciptakan karya desain dengan ikon interface berupa tombol yang secara visual merepresentasikan identitas alat tersebut serta penyerupaan fungsifungsinya.

Ketika seorang seniman maupun desainer visual merancang dan mencipta sebuah karya seni maka terdapat banyak variabel yang dijadikan aspek pendukung terciptanya karya dengan visual tertentu. Sebagai contoh hal paling mendasar ketika mempelajari nirmana secara praktik, awalan kompetensi yang harus dikuasai adalah kemampuan menggoreskan alat pewarna untuk mengisi bidang tertentu secara rata, rapi, konstan dan stabil. Penguasaan dasar yang sederhana ini memerlukan dukungan variable lainnya, misal ketepatan menentukan alat, ketepatan memilih bahan, ketepatan dalam teknis menggores misal arah goresan, tekanan goresan dan kestabilan tangan menggores. Satu kompetensi dasar ini masih memerlukan penguasaan dari factor internal dari seniman atau desainernya misalnya ketenangan kejiwaan, kondisi psikologis dan tingkat kemapanan biologis dan fisiologis. Dari keseluruhan variable pendukung diatas maka dipintaskan dalam software digital dengan satu kali gerakan klik pada obyek yang terseleksi maka semua tahapan dalam mewarna secara analog bisa dilakukan dalam satu klik yang tak lebih dari satu detik.

b. Coupling and Cohesion.

Coupling adalah proses menentukan relasi antar modul sedangkan cohesion adalah proses menentukan bagaimana setiap element agar bisa merelasikan modul-modul tersebut. Dalam software CorelDRAW coupling terjadi pada bagaimana relasi yang terjadi pada setiap tools yang ada dalam toolbox interface. Semua tool dalam toolbox tersebut memiliki relasi jika salah satu tool digunakan untuk merubah sebuah wujud obyek tertentu maka parameter dan property dari obyek tersebut ikut merubah parameter dan property tool yang lain. Sebagai contoh sebuah lingkaran yang diubah skalanya dengan pick tool, maka secara otomatis area warna pada obyek tersebut berubah skalanya menyesuaikan skala bidang obyek. Sedangkan proses cohesion dalam CorelDRAW terjadinya setiap tools dalam toolbox yang mampu merelasikan semua tools yang terdapat dalam toolbox.

\section{c. Decomposition and Modularization.}

Proses dekompisisi dan mudulasi merupakan pemecahan software yang kompleks kedalam sejumlah modulmodul kecil yang saling berelasi (Swebok, 2004). Bambang Hariyanto (2004) berpendapat ada 2 (dua) jenis dekomposisi yaitu: dekomposisi algoritmik dan dekomposisi berorientasi objek.

1) Dekomposisi algoritmik adalah proses pendekatan yang sering dilakukan dalam pemograman terstruktur dimana pada pendekatan ini difokuskan pada proses/algoritma/fungsi yang memanipulasi struktur data.

Pada software CorelDRAW dekomposisi algoritmik menggunakan pendekatan manipulasi struktur data dengan cara menjadikan semua tools 
memiliki atribut data yang mengakomodasi semua kebutuhan yang mendekati seolah-olah sama dengan pengerjaan karya non digital. Dekomposisi algoritmik dirancang untuk menjadikan fungsi-fungsi tools pada toolbox CorelDraw seolah sama dalam hasil pengolahan sebuah obyek dalam pengerjaan karya rupa maupun desain secara analog. Untuk mendekati fungsi-fungsi tersebut maka setiap tools disematkan atribut yang bisa diatur parameter agar mendekati hasil pada pengerjaan secara non digital, pengaturan parameter tools dilakukan dengan merubah besaran angka sesuai ukuran yang dikehendaki.

2) Dekomposisi berorientasi objek adalah proses pendekatan pemecahan permasalahan menjadi objek-objek yang saling berinteraksi, jadi pada pendekatan ini, kita tidak melakukan bagaimana sebuah permasalahan diselesaikan, akan tetapi mengidentifikasi objek-objek yang berkolaborasi dalam permasalahan yang dihadapi, sedangkan proses penyelesaian permasalahan ditangani dalam bentuk peran dan tanggung jawab objek-objek yang sudah didefinisikan.

Pada software CorelDRAW dekomposisi berorientasi pada objek dapat diidentifikasi pada semua tools pada toolbox. Permasalahanpermasalah yang muncul dalam sebuah pengerjaan desain maupun karya rupa, tidak diberikan solusi secara jalan pintas dengan satu langkah saja, namun disediakan tools yang harus dikombinasikan dengan pola dan strategi tertentu untuk dapat memecahkan permasalahan yang dihadapi.

\section{d. Encapsulation/Information Hiding}

(Penyembunyian Informasi)

Encapsulation/information

hiding

merupakan proses pengelompokan dan pemaketan element-element dan detail informasi abstraksi sehingga tidak bisa diakses oleh sembarang proses/objek ataupun prosedur tertentu (Swebok, 2004) sedangkan pendapat lain mengatakan bahwa encapsulation /information hiding adalah proses memisahkan aspek-aspek eksternal objek yang dapat diakses objek-objek lain dari rincian-rincian implementasi internal objek yang tersembunyi dari objek-objek lain (Bambang Hariyanto, 2004).

Sebagai contoh, dalam sebuah bidang kerja terdapat objek yang memiliki cakupan area-area tertentu, jika kita hendak mengganti warna salah satu obyek maka obyek yang lain yang tidak kita seleksi tidak akan terjadi perubahan warna. Sama halnya dengan kehidupan nyata, jika kita telah menciptakan sketsa misalnya lingkaran dan bintang, kemudian kita hendak mewarnai area bintang terlebih dahulu sesuai wujud bintang, maka area lingkaran tidak akan terpengaruh/tidak ikut terwarnai dengan otomatis. Namun selain pilihan seleksi, dalam CorelDRAW terdapat juga fitur grup dan ungrup, dimana ketika beberpa obyek di grup, maka secara bersamaan semua objek dalam grup tersebut bisa diganti dalam satu waktu.

e. Separation of Interface and Implementation. 
Separating interface and implementation adalah proses mendefinisikan sebuah komponen dengan spesifikasi sebuah public interface, diketahui oleh client, memisahkan detail informasi dan bagaimana komponen direalisasikan (Swebok, 2004).

Sebagai contoh, secara analog ketika kita menggaris maka ukuran goresan garisan yang kita buat tergantung pada penggunaan alatnya, misalnya menggunakan drawing pen, maka ukuran goresan tergantung besaran size mata penanya misal 0.0, 0.1, 1 dan seterusnya. Hal ini berlaku pula untuk alat penggores misal kuas, maka besaran garis mengikuti bentuk rambut kuas misal pipih atau lancip dan ukuran kuas misal 0.0, 0, 1, 2 dan seterusnya. Selebihnya ukuran goresan secara analog dipengaruhi factor lain misal cara memegang alat, arah sudut kemiringan alat, karakter bahan serta tingkatan ekspresi seniman/desainernya. Namun ketika diintepretasikan kedalam software maka satu garis diberikan spesifikasi dan parameter dalam mnegidentifikasikan property dari garis tersebut. Sebuah garis memiliki atribut ukuran yang konstan dan terukur, dalam software CorelDRAW ukuran garis diberikan satuan point (pt), inches (in), centimeters ( $\mathrm{cm})$, picas (pc), pixel ( $p x)$, ciceros (cc), didots ( $d d)$, feet ( $f t)$, yards $(y d)$, miles $(m i)$, meters $(m)$, kilometers $(\mathrm{km}), \mathrm{Q}(\mathrm{Q})$ dan $\mathrm{H}(\mathrm{H})$, dimulai dari 0,1 pt, 0,2 pt sampai tak terhingga, penyesuaian ukuran tinggal memasukkan angka sesuai ukuran garis yang diinginkan. Adapun ukuran diberikan spesifikasi nama "width" secara default dengan posisi paling atas yakni none (yakni tidak bergaris), hairline yakni ukuran dibawah 0.5, kemudian 0,75 hingga 36 point. Kemudian ada spesifikasi style yakni secara default terdapat 20 style garis yang disediakan. Spesifikasi Dashes dan corner sebagai fasilitas mengatur sudut garis. Linecaps sebagai pengatur ujung garis dan position untuk mengatur posisi arah garis. Arrowheads untuk mengatur arah dan gerakan panah dari garis, dalam parameter calligraphy untuk menentukan kemiringan sudut goresan untuk menciptakan kedinamisan garis.

f. Sufficiency, Completeness and Primitiveness.

Sufficiency, completeness and primitiveness adalah proses meyakinkan bahwa semua komponen yang membentuk software mampu menangani dan menampung semua karateristik dari sebuah abstraksi (Swebok, 2004).

Dalam toolbox pada software CorelDRAW, tools yang disediakan dimaksudkan untuk mengakomodasi keperluan-keperluan dalam menciptakan sebuah karya visual. Permasalahanpermasalahan dalam perancangan sebuah karya diberikan cara dan solusinya dengan kombinasi antar tools.

\section{Hasil penentuan relasi tools pada toolbox dengan unsur-unsur nirmana berdasarkan fungsinya}

Setelah teridentifikasi fungsi masingmasing tools maka terdapat relasi dengan unsur-unsur nirmana, berikut adalah hasil penentuan relasi tersebut:

Tabel 3 Fungsi masing-masing tools dan relasi dengan unsur-unsur nirmana

\begin{tabular}{c|c|c|c}
\hline No. & $\begin{array}{c}\text { Nama } \\
\text { tools }\end{array}$ & Nama sub-tools & $\begin{array}{l}\text { Relasi dengan } \\
\text { unsur nirmana }\end{array}$ \\
\hline
\end{tabular}




\begin{tabular}{|c|c|c|c|}
\hline 1. & $\begin{array}{l}\text { Pick } \\
\text { Tool }\end{array}$ & Pick Tool & - \\
\hline 2. & & $\begin{array}{l}\text { Freehand Pick } \\
\text { Tool }\end{array}$ & - \\
\hline 3. & $\begin{array}{l}\text { Shape } \\
\text { Edit Tool }\end{array}$ & Shape Tool & Bidang/shape \\
\hline 4. & & $\begin{array}{l}\text { Smudge Brush } \\
\text { Tool }\end{array}$ & Bidang/shape \\
\hline 5. & & $\begin{array}{l}\text { Roughen Brush } \\
\text { Tool }\end{array}$ & Bidang/shape \\
\hline 6. & & $\begin{array}{l}\text { Free Transform } \\
\text { Tool }\end{array}$ & Bidang/shape \\
\hline 7. & & Twirl Tool & Bidang/shape \\
\hline 8. & & Attract Tool & Bidang/shape \\
\hline 9. & & Repel Tool & Bidang/shape \\
\hline 10. & $\begin{array}{l}\text { Crop } \\
\text { Tool } \\
\end{array}$ & Crop Tool, & Bidang/shape \\
\hline 11. & & Knife Tool & Bidang/shape \\
\hline 12. & & Eraser Tool & Bidang/shape \\
\hline 13. & & $\begin{array}{l}\text { Virtual Segment } \\
\text { Delete, }\end{array}$ & Bidang (shape) \\
\hline 14. & $\begin{array}{l}\text { Zoom } \\
\text { Tool }\end{array}$ & Zoom Tool & - \\
\hline 15. & & Pan Tool & - \\
\hline 16. & $\begin{array}{l}\text { Freehan } \\
\text { d Tool }\end{array}$ & Freehand Tool & $\begin{array}{l}\text { Unsur Garis } \\
\text { (line) }\end{array}$ \\
\hline 17. & & $\begin{array}{l}\text { 2-Point Line } \\
\text { Tool }\end{array}$ & $\begin{array}{l}\text { Unsur Garis } \\
\text { (line) }\end{array}$ \\
\hline 18. & & Bezier Tool & $\begin{array}{l}\text { Unsur Garis } \\
\text { (line) }\end{array}$ \\
\hline 19. & & $\begin{array}{l}\text { Artistic Media } \\
\text { Tool }\end{array}$ & $\begin{array}{l}\text { Unsur Garis } \\
\text { (line) }\end{array}$ \\
\hline 20. & & Pen Tool & $\begin{array}{l}\text { Unsur Garis } \\
\text { (line) }\end{array}$ \\
\hline 21. & & B-Spline Tool & $\begin{array}{l}\text { Unsur Garis } \\
\text { (line) }\end{array}$ \\
\hline 22. & & Polyline Tool & $\begin{array}{l}\text { Unsur Garis } \\
\text { (line) }\end{array}$ \\
\hline 23. & & 3-Point Curve & $\begin{array}{l}\text { Unsur Garis } \\
\text { (line) }\end{array}$ \\
\hline 24. & $\begin{array}{l}\text { Smart } \\
\text { Fill Tool } \\
\end{array}$ & Smart Fill Tool & $\begin{array}{l}\text { Unsur Bidang } \\
\text { (shape) }\end{array}$ \\
\hline 25. & & Smart Drawing & $\begin{array}{l}\text { Unsur Bidang } \\
\text { (shape) }\end{array}$ \\
\hline 26. & $\begin{array}{l}\text { Rectangl } \\
\text { e Tool }\end{array}$ & Rectangle Tool & $\begin{array}{l}\text { Unsur Bidang } \\
\text { (shape) }\end{array}$ \\
\hline 27. & & $\begin{array}{l}\text { 3-Point } \\
\text { Rectangle }\end{array}$ & $\begin{array}{l}\text { Unsur Bidang } \\
\text { (shape) }\end{array}$ \\
\hline 28. & $\begin{array}{l}\text { Ellips } \\
\text { Tool }\end{array}$ & Ellips Tool & $\begin{array}{l}\text { Unsur Bidang } \\
\text { (shape) }\end{array}$ \\
\hline 29. & & 3-Point Ellips & $\begin{array}{l}\text { Unsur Bidang } \\
\text { (shape) }\end{array}$ \\
\hline 30. & $\begin{array}{l}\text { Polygon } \\
\text { Tool } \\
\end{array}$ & Polygon Tool & $\begin{array}{l}\text { Unsur Bidang } \\
\text { (shape) }\end{array}$ \\
\hline 31. & & Star Tool & $\begin{array}{l}\text { Unsur Bidang } \\
\text { (shape) }\end{array}$ \\
\hline 32. & & $\begin{array}{l}\text { Complex Star } \\
\text { Tool }\end{array}$ & $\begin{array}{l}\text { Unsur Bidang } \\
\text { (shape) }\end{array}$ \\
\hline 33. & & $\begin{array}{l}\text { Graph Paper } \\
\text { Tool }\end{array}$ & $\begin{array}{l}\text { Unsur Bidang } \\
\text { (shape) }\end{array}$ \\
\hline 34. & & Spiral Tool & $\begin{array}{l}\text { Unsur Bidang } \\
\text { (shape) }\end{array}$ \\
\hline
\end{tabular}

\begin{tabular}{|c|c|c|c|}
\hline 35. & $\begin{array}{l}\text { Basic } \\
\text { Shapes } \\
\text { Tool } \\
\end{array}$ & $\begin{array}{l}\text { Basic Shapes } \\
\text { Tool }\end{array}$ & $\begin{array}{l}\text { Unsur Bidang } \\
\text { (shape) }\end{array}$ \\
\hline 36. & & $\begin{array}{l}\text { Arrow Shapes } \\
\text { Tool }\end{array}$ & $\begin{array}{l}\text { Unsur Bidang } \\
\text { (shape) }\end{array}$ \\
\hline 37. & & $\begin{array}{l}\text { Flowchart } \\
\text { Shapes Tool }\end{array}$ & $\begin{array}{l}\text { Unsur Bidang } \\
\text { (shape) }\end{array}$ \\
\hline 38. & & Banner Shapes & $\begin{array}{l}\text { Unsur Bidang } \\
\text { (shape) }\end{array}$ \\
\hline 39. & & Callout Shapes & $\begin{array}{l}\text { Unsur Bidang } \\
\text { (shape) }\end{array}$ \\
\hline 40. & $\begin{array}{l}\text { Text } \\
\text { Tool }\end{array}$ & & $\begin{array}{l}\text { Unsur Bidang } \\
\text { (shape) }\end{array}$ \\
\hline 41. & $\begin{array}{l}\text { Table } \\
\text { Tool }\end{array}$ & & $\begin{array}{l}\text { Unsur Bidang } \\
\text { (shape) }\end{array}$ \\
\hline 42. & $\begin{array}{l}\text { Parallel } \\
\text { Dimensi } \\
\text { on Tool }\end{array}$ & $\begin{array}{l}\text { Parallel } \\
\text { Dimension Tool }\end{array}$ & $\begin{array}{l}\text { Unsur Garis } \\
\text { (line) }\end{array}$ \\
\hline 43. & & $\begin{array}{l}\text { Horizontal or } \\
\text { Vertical } \\
\text { Dimension Tool } \\
\end{array}$ & $\begin{array}{l}\text { Unsur Garis } \\
\text { (line) }\end{array}$ \\
\hline 44. & & $\begin{array}{l}\text { Angular } \\
\text { Dimension Tool }\end{array}$ & $\begin{array}{l}\text { Unsur Garis } \\
\text { (line) }\end{array}$ \\
\hline 45. & & $\begin{array}{l}\text { Segment } \\
\text { Dimension Tool }\end{array}$ & $\begin{array}{l}\text { Unsur Garis } \\
\text { (line) }\end{array}$ \\
\hline 46. & & 3-Point Callout & $\begin{array}{l}\text { Unsur Garis } \\
\text { (line) Garis } \\
\text { (line) }\end{array}$ \\
\hline 47. & $\begin{array}{l}\text { Straight- } \\
\text { Line } \\
\text { Connect } \\
\text { or Tool }\end{array}$ & $\begin{array}{l}\text { Straight-Line } \\
\text { Connector Tool }\end{array}$ & $\begin{array}{l}\text { Unsur Garis } \\
\text { (line) Garis } \\
\text { (line) }\end{array}$ \\
\hline 48. & & $\begin{array}{l}\text { Right-Angle } \\
\text { Connector Tool }\end{array}$ & $\begin{array}{l}\text { Unsur Garis } \\
\text { (line) }\end{array}$ \\
\hline 49. & & $\begin{array}{l}\text { Right-Angle } \\
\text { Round } \\
\text { Connector Tool }\end{array}$ & $\begin{array}{l}\text { Unsur Garis } \\
\text { (line) }\end{array}$ \\
\hline 50. & & Edit Anchor & $\begin{array}{l}\text { Unsur Garis } \\
\text { (line) }\end{array}$ \\
\hline 51. & $\begin{array}{l}\text { Blend } \\
\text { Tool }\end{array}$ & Blend Tool & $\begin{array}{l}\text { Unsur Bidang } \\
\text { (shape) }\end{array}$ \\
\hline 52. & & Contour Tool & $\begin{array}{l}\begin{array}{l}\text { Unsur Bidang } \\
\text { (shape) }\end{array} \\
\end{array}$ \\
\hline 53. & & Distort Tool & $\begin{array}{l}\text { Unsur Bidang } \\
\text { (shape) }\end{array}$ \\
\hline 54. & & $\begin{array}{l}\text { Drop Shadow } \\
\text { Tool }\end{array}$ & $\begin{array}{l}\text { Unsur Gempal } \\
\text { (volume) dan } \\
\text { unsur ruang }\end{array}$ \\
\hline 55. & & Envelope Tool & $\begin{array}{l}\text { Unsur Bidang } \\
\text { (shape) }\end{array}$ \\
\hline 56. & & Extrude Tool & $\begin{array}{l}\text { Unsur Gempal } \\
\text { (volume) dan } \\
\text { unsur ruang }\end{array}$ \\
\hline 57. & & $\begin{array}{l}\text { Transparency } \\
\text { Tool }\end{array}$ & $\begin{array}{l}\text { Unsur Gempal } \\
\text { (volume) }\end{array}$ \\
\hline 58. & $\begin{array}{l}\text { Color } \\
\text { Eyedrop } \\
\text { per Tool }\end{array}$ & $\begin{array}{l}\text { Color } \\
\text { Eyedropper } \\
\text { Tool } \\
\end{array}$ & Unsur Warna \\
\hline 59. & & $\begin{array}{l}\text { Attribute } \\
\text { Eyedropper } \\
\text { Tool } \\
\end{array}$ & Unsur Warna \\
\hline
\end{tabular}




\begin{tabular}{l|l|l|l}
\hline 60. & $\begin{array}{l}\text { Outline } \\
\text { Pen }\end{array}$ & Outine Pen & $\begin{array}{l}\text { Unsur Garis } \\
\text { (line) }\end{array}$ \\
\hline 61. & & Outline Colors & $\begin{array}{l}\text { Unsur Garis } \\
\text { (line) dan warna }\end{array}$ \\
\hline 62. & & No Outline & $\begin{array}{l}\text { Unsur Garis } \\
\text { (line) }\end{array}$ \\
\hline 63. & & Hairline Outline & $\begin{array}{l}\text { Unsur Garis } \\
\text { (line) }\end{array}$ \\
\hline 64. & & Color & Unsur warna \\
\hline 65. & Fill Tool & Uniform Fill & Unsur warna \\
\hline 66. & & Fountain Fill & Unsur warna \\
\hline 67. & & Pattern Fill & Unsur Tekstur \\
\hline 68. & & Texture Fill & Unsur Tekstur \\
\hline 69. & & PostScript Fill & Unsur Tekstur \\
\hline 70. & & No Fill & Unsur Tekstur \\
\hline 71. & & Color & $\begin{array}{l}\text { Unsur Tekstur } \\
\text { dan unsur warna }\end{array}$ \\
\hline 72. & $\begin{array}{l}\text { Interacti } \\
\text { ve Fill } \\
\text { Tool }\end{array}$ & $\begin{array}{l}\text { Interactive Fill } \\
\text { Tool }\end{array}$ & $\begin{array}{l}\text { Unsur bidang, } \\
\text { unsur warna, } \\
\text { unsur gempal }\end{array}$ \\
\hline 73. & & Mesh Fill & $\begin{array}{l}\text { Unsur bidang, } \\
\text { unsur warna, } \\
\text { unsur gempal }\end{array}$ \\
\hline
\end{tabular}

Dari hasil analisis relasi antara tools pada toolbox CorelDRAW dengan unsur-unsur nirmana maka didapati data sebagai berikut:

Tabel 4 jumlah relasi unsur-unsur nirmana dengan tools dalam toolbox CorelDRAW

\begin{tabular}{l|c|l}
\hline Unsur & $\begin{array}{c}\text { Jumlah } \\
\text { relasi } \\
\text { dengan } \\
\text { tools }\end{array}$ & keterangan \\
\hline Titik & - & $\begin{array}{l}\text { Dalam CorelDRAW unsur } \\
\text { titik dinamai node, sifatnya } \\
\text { invisible, baru muncul jika } \\
\text { dijadikan garis atau bidang }\end{array}$ \\
\hline Garis & 21 & $\begin{array}{l}\text { Garis digunakan untuk } \\
\text { mencipta bidang dengan } \\
\text { bentuk yang tidak terbatas, } \\
\text { ada yang disediakan secara } \\
\text { default misal obyek-obyek } \\
\text { geometrical, dan bentuk- } \\
\text { bentuk bebas menggunakan } \\
\text { tools yang beragam }\end{array}$ \\
\hline Bidang & 24 & $\begin{array}{l}\text { Tools } \text { untuk keperluan } \\
\text { penciptaan bidang adalah yang } \\
\text { paling banyak, ada } 24 \text { tools } \\
\text { yang disiapkan untuk } \\
\text { mengakomodasi pembuatan } \\
\text { bidang }\end{array}$ \\
\hline Gempal/ & 5 & $\begin{array}{l}\text { CorelDRAW merupakan } \\
\text { software design berbasis } \\
\text { vector, untuk menciptakan } \\
\text { gempal volume tidak } \\
\text { disediakan 5 tools namun }\end{array}$ \\
\hline
\end{tabular}

\begin{tabular}{l|c|l}
\hline & & $\begin{array}{l}\text { harus dikombinasikan } \\
\text { dengan tools yang lain }\end{array}$ \\
\hline Ruang & 2 & $\begin{array}{l}\text { Ruang muncul karena adanya } \\
\text { susunan bidang dan garis, } \\
\text { sehingga dalam CorelDRAW } \\
\text { hanya menyediakan 2 tools } \\
\text { untuk mengakomodasi unsur } \\
\text { ruang }\end{array}$ \\
\hline Warna & 8 & $\begin{array}{l}\text { Dalam software vector } \\
\text { pewarnaan sifatnya 2 } \\
\text { dimensional yang plane dan } \\
\text { datar, meskipun terdapat tools } \\
\text { untuk pewarnaan yang } \\
\text { sifatnya gradasi }\end{array}$ \\
\hline Tekstur & 5 & $\begin{array}{l}\text { Tekstur dalam CorelDRAW } \\
\text { sangat terbatas secara default, } \\
\text { namun bisa dikombinasikan } \\
\text { dengan menambahkan image } \\
\text { lain atau membuat secara } \\
\text { costum }\end{array}$ \\
\hline
\end{tabular}

Meskipun ada anggapan penguasaan skill nirmana sudah tergantikan dengan tools perangkat lunak, namun jika kita teliti lebih mendalam, maka sebenarnya perangkat lunak CorelDRAW tidak lepas dari unsur-unsur teori nirmana. Dari hasil penelitian diatas ditemukan bahwasanya dari 73 tools dalam toolbox corelDRAW 71 diantaranya adalah perangkat yang disediakan untuk mengakomodasi penerapan unsur-unsur nirmana dalam merancang karya seni rupa maupun desain.

Penelitian ini berhasil mengidentifikasi penerapan teori-teori nirmana yakni unsurunsur Nirmana Dwimatra yang terdapat pada perangkat lunak desain CorelDRAW. Adanya relasi dan kaitan unsur-unsur rupa yang terdapat dalam nirmana yang awalnya dipenguasaan teori maupun teknis praktiknya secara manual/analog yakni pola pengerjaan teknis menggunakan peralatan-peralatan dan bahan yang sifatnya non digital, berupa peralatan-peralatan yang umum diguanakan dalam pengerjaan produk senirupa untuk kemudian digantikan dan diterapkan dalam pengerjaan karya berbasis digital yakni direpresntasikan kedalam tools, menu, 
submenu secara perangkat lunak digital CorelDRAW.

Nirmana sebagai ground theory, secara fundamental dijadikan landasan paling awal dalam perkembangan sejarah seni rupa, Nirmana diistilahkan sebagai elements of art, basic principles of design telah ditulis dan dirumuskan dalam berbagai buku baik dari penulis internasional maupun dalam negeri, salah satu buku Nirmana yang paling sering digunakan sebagai rujukan adalah buku Nirmana, elemen-elemen seni rupa dan desain. Dalam perkembangan era digital ketika piranti berkesenirupaan dan desain digantikan dengan perangkat lunak berbasis digital nyatanya ada pola-pola relasi pada toolbox-nya, hanya saja korelasi tersebut mengalami perubahan yakni dalam hal atribut dan penggunaanya menyesuaikan behaviornya digital.

Artinya ada relasi dan korelasi yang bisa diidentifikasi antara nirmana sebagai ground theory dan CorelDraw sebagai piranti perangkat lunak. Korelasi tersebut berupa konversi dan interpretasi piranti-piranti perangkat analog kedalam piranti-piranti digital yang secara sifat dan fungsional sama atau mendekati sama dengan sifat dan karakter yang mengalami penyesuaian-penyesuaian.

\section{DAFTAR PUSTAKA}

[1] Ambrose, Gavin, Paul Harris. 2008. The Producon Manual (A Grafik Design Handbook). Singapura: AVA Book Production Pte

[2] Bambang Hariyanto, Rekayasa Sistem Berorientasi Objek. 2004. Bandung: Informatika

[3] Chandra. (2005). Coreldraw dan Photoshop untuk Grafis Percetakan, Palembang: Maxikom.

[4] Corel "A short history of CorelDRAW, Celebrating 20 years of innovation in design" official websites Corel Corporation,

[5] Corel, CorelDraw Graphics Suite 12 User Guide, 2007, www.ebookee.com.

[6] Ebdi, Sadjiman S. 2009. Nirmana; Elemen-elemen seni dan desain (edisi ke2). Yogyakarta; Jalasutra.

[7] Pender, T. A. 2002. UML Weekend Crash Course. Indianapolis: Wiley Publishing, Inc.

[8] Rustandi Iim, 2007. Membuat Desain Kreatif Dengan CorelDraw X3, Jakarta: Elex Media Komputindo.

[9] Sidik, Fadjar dan Aming Prayitno. Desain Elementer, Yogyakarta : STSRI. ASRI, 1979.

[10]Wong, Wucius. (1986) Beberapa Azas Menggambar Dwi Matra. Bandung 